\title{
Scope for Increasing the Participation of the Chronically Poor in Economic Growth
}

McKay, Andy; Shepherd, Andrew; Prowse, Martin

Publication date:

2007

Document version

Publisher's PDF, also known as Version of record

Citation for published version (APA):

McKay, A., Shepherd, A., \& Prowse, M. (2007). Scope for Increasing the Participation of the Chronically Poor in Economic Growth. http://www.chronicpoverty.org/uploads/publication_files/CPR2_Background_Papers_MckayShepherd-Prowse.pdf 


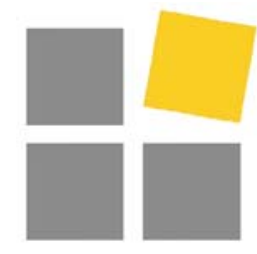

\section{Chronic Poverty Research Centre}

\section{Scope for Increasing the Participation of the Chronically Poor in Economic Growth}

\section{What is Chronic Poverty?}

The distinguishing feature of chronic poverty is

extended duration in absolute poverty.

Therefore, chronically poor people always, or usually,

live below a poverty line, which is normally defined in terms of a money indicator (e.g. consumption, income, etc.), but could also be defined in terms of wider or subjective aspects of deprivation.

This is different from the transitorily poor, who move in and out of poverty, or only occasionally fall below the poverty line.

\author{
Andy McKay \\ Andrew Shepherd \\ Martin Prowse
}

June 2007
The research for this Background Paper was made possible by funding from the United States Agency for International Development (USAID) (via BASIS Collaborative Research Support Program at the University of Wisconsin-Madison). 


\section{Table of Contents}

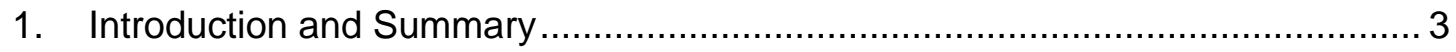

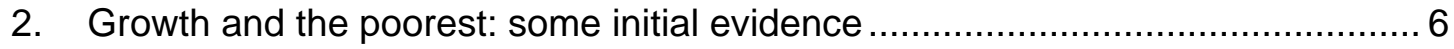

3. The chronically poor, poverty transitions and markets................................... 8

4. Key issues in facilitating escapes from chronic poverty ............................... 15

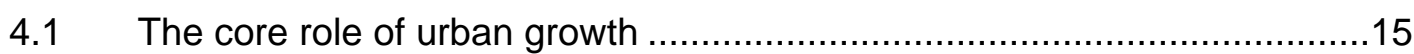

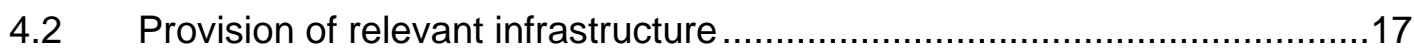

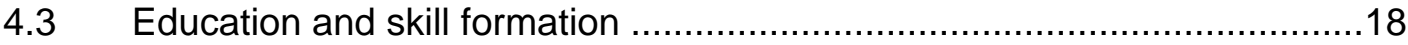

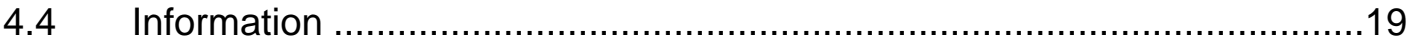

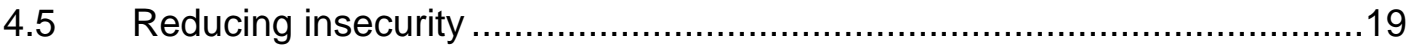

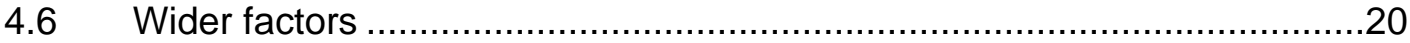

5. Supporting Growth in Difficult Policy Environments ........................................ 22

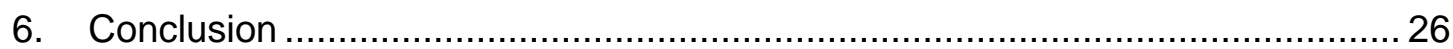

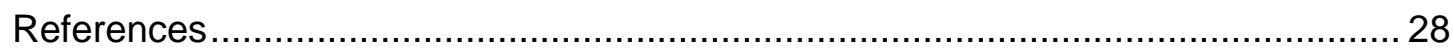




\section{Introduction and Summary}

It is now well known that there are often significant changes in households' living conditions over time; and these dynamics can be associated with significant movements into and out of poverty. Other households, though, can remain trapped in poverty for substantial periods of time - the chronically poor. Whilst there are a wide range of policy actions that may be important for poverty reduction, there is very strong cross-country evidence for the importance of economic growth for poverty reduction - reaffirmed by the recent multi-country Operationalising Pro-Poor Growth (OPPG) project (Besley and Cord, 2007; Grimm et al, 2007). The extent to which growth translates into poverty reduction varies from case to case, depending on many factors: the distributional pattern of growth, the starting level of inequality, population growth, and how the benefits of growth are distributed across the population by the operation of markets, government action, non-state actors and private transfers. The core question here is the ability of the poor to participate directly in growth, or to benefit indirectly from the additional revenue growth generates. At the same time, the process of growth can have important adverse impacts on the poor, for example through the loss of employment or livelihoods associated with economic restructuring.

This synthesis paper focuses specifically on the relationship between economic growth and the chronically poor. To what extent are the chronically poor able to participate in growth or from the benefits of growth? What factors enhance or restrict this ability? To what extent is growth accompanied by households falling back into poverty, and if so what processes underlie this? And what policy implications can be drawn out for governments and development partners? ${ }^{1}$

Of course, many people living in chronic poverty in the world are likely to live in countries which have not experienced economic growth in the recent past. This may be a consequence of many different factors including social and political instability (including conflict) or climatic, trade or other shocks. CPRC has identified a group of 'chronically deprived countries', which have progressed little on basic human welfare during the last 30-40 years (Anderson, 2007). In such an environment it is to be expected that very few people will be able to escape from poverty. The challenge in such an environment is to re-launch sustainable growth, and then, critically, to sustain it; and from the perspective of this paper the challenge is how to ensure that the poor in general - and the chronically poor specifically - are able to benefit from this.

\footnotetext{
${ }^{1}$ A supplementary question we would like to be able to answer, but cannot at present, is the extent to which exits from poverty are to a level, possibly well above the poverty line, from which returns to poverty are unlikely. This needs further research, which will be carried out in the next few months.
} 
There is limited empirical evidence on these questions to date. Much of the analysis of the relationship between growth and poverty reduction has focused on repeated cross-section surveys, where it is not possible to follow the same individuals or households over time. In this way it is possible to look at changes in the overall level of poverty; but not at the dynamics (movements in and out) that underlie this, nor to identify the chronically poor specifically. A possible proxy for the chronically poor may be to look at the poorest among the poor. This is an imperfect proxy both conceptually and because of measurement error - but it may nonetheless offer important insights, which are briefly discussed in Section 2 below.

To look at poverty dynamics requires panel survey data, following the same individuals over time. This project has commissioned five country case studies drawing on panel data (rural Ethiopia, rural India, Nicaragua, Uganda and Vietnam) analysing the relationship between growth and poverty dynamics. The terms of reference for these case studies asked for a specific focus on the role of markets in enabling (or not) the chronically poor to participate in growth; and (where possible) to look at both urban and rural areas. The extent to which this could be realised in practice in each country case depended on the available data. Section 3 below highlights some of the key characteristics of the chronically poor identified in the country studies, while the core Section 4 attempts to synthesise the key findings of these diverse country experiences about the link between poverty dynamics and growth.

In contrast to Sections 2-4, which focus on poverty dynamics in growth environments where donor agencies have found it possible to develop major consistent aid programmes, Section 5 focuses on poverty dynamics and markets in various 'difficult national policy environments' (Sudan, Zimbabwe, Malawi). Such states are sometimes labelled 'fragile states' - politically and/or economically unstable, with the suggestion that if not already subject to extended violent internal conflict, they are judged to be heading towards this or some other aspect of state failure (there is a significant overlap between these categories, and that of chronically deprived countries mentioned above).

However, state 'fragility' reconfigures and stymies the 'conventional' relationship between economic growth and the chronically poor discussed in Sections 2 - 4 . Examining this relationship is difficult and complex - not only because the term 'fragile states' is an unhelpful composite of varying degrees of political will and institutional capacity (DfID, 2005), but also because growth trends in 'fragile' states vary widely, as exemplified in our three country cases. In Section 5 we focus on the substantial overlap between reducing chronic poverty in these contexts, and addressing some of the drivers and maintainers of 'fragility' through fostering the 'social contract' between citizens and the state, which may be core contributors to both chronic poverty and poor, volatile or very unequal growth patterns.

Section 6 concludes the paper by outlining the main policy implications, dividing these into those that are more definite, where evidence is strong, and more 
speculative where there are plausible hypotheses but evidence is still lacking. More definite lessons focus on infrastructure and urbanisation, regional policy, agricultural growth, human capital, and stronger understanding of labour markets; more tentative conclusions stress finance for SMEs, the role of information, and the absence of alternatives to transformative growth.

\section{Acknowledgements}

The research for this Background Paper was made possible by funding from the United States Agency for International Development (USAID) (via BASIS Collaborative Research Support Program at the University of Wisconsin-Madison).

\section{Authors}

Andy McKay is Professor of Development Economics at the University of Sussex and Associate Director of the Chronic Poverty Research Centre.

Email: A.Mckay@sussex.ac.uk

Andrew Shepherd is Director of the Chronic Poverty Research Centre and Director of Programmes, Rural Policy and Governance Group at the Overseas Development Institute, London

Email: a.shepherd@odi.org.uk

Martin Prowse is a Research Officer at the Overseas Development Institute, London.

Email: m.prowse@odi.org.uk 


\section{Growth and the poorest: some initial evidence}

A specific focus on the change in the living conditions of the poorest (say the bottom $10 \%$ or $20 \%$ ) between two or more periods of time may provide important indications of the participation of this group in growth. However, this approach does not provide information about dynamics, as the composition of the poorest might change significantly over time (for example, if it is related to life-cycle factors). As such it is not focusing specifically on the chronically or persistently poor. But if there is a sufficiently strong correlation between the chronically poor and the poorest at any point in time (an untested assumption), this may provide an adequate approximate indication of the participation of the chronically poor in growth.

The recent Operationalising Pro-Poor Growth (OPPG) project summarised changes in the distribution of living standards in 14 countries by means of growth incidence curves (GICs) (see Ravallion and Chen, 2003), thus enabling an examination of growth rates in real household consumption/income per capita/adult over the 1990s for different percentile groups in the distribution. Grant (2005) provides a summary of the implications of the changes in the GICs for the poorest in each country, and summarises the analysis in the country papers about why the poorest were - or were not - able to participate in growth. The use of the GIC has the attraction of not having to focus on a unique, arbitrary definition of the poorest.

The analysis shows that in most cases of growth, the living standards of the poorest also tended to increase; but they generally increased at a slower rate. In most OPPG case studies where the country showed good growth performance inequality tended to increase; and one aspect of this was that the average growth rates among the poorest were lower than for other groups. On the other hand, in cases where growth was slow or negative, the poorest often did better - or suffered less - in terms of growth than the national average; but because the growth rates were modest or negative, their living standards either changed little or worsened. In summary, in good growth environments the poorest were generally less able to participate in growth (or derived less benefit) than the average household; but in weak or negative growth environments they tended not to suffer more. The country-specific explanations vary from case to case, but one common factor in many cases is agriculture, from which a significant proportion of the poorest derive their livelihoods. Agricultural growth tended to be slower than other sectors in the faster growing countries; while in slower growing or declining countries agriculture provided something of a buffer for weak performance in non-agricultural sectors.

This suggests that policies to promote agricultural growth in the short to medium term are especially important in slower growing economies, while longer term growth strategies are constructed. In general there is significant evidence that it is relatively straightforward to initiate growth, but somewhat more difficult to sustain it (Rodrik, 2004). This applies specifically to the agricultural sector: there is some evidence to suggest that, while it is not too difficult to engineer agricultural growth in the first 
place, including through green revolution type approaches, the more difficult challenge is to sustain growth in the long term (Mosley et al, 2006). Agriculture also has social protection functions which need to be recognised and possibly bolstered (though the science of this is at an early stage).

It is also important to consider the impact of growth on non-income indicators of wellbeing, including for the poorest; these indicators are important dimensions of wellbeing in their own right, but also potentially important influences on future growth. Klasen (2005) finds in Bolivia that education levels increased with growth throughout the income distribution with the poorest benefiting disproportionately (although, of course, this was from a lower starting point). Anderson (2005) finds mixed evidence in relation to the poorest in Ghana and Uganda through the growth of the 1990s. The poorest in both countries experienced significant increases in educational enrolment and completion; but child vaccination rates worsened in Uganda; and $12 \%$ of Ghanaian households remained without any assets, and so vulnerable to shocks. Overall, in Ghana most human development indicators improved to a much greater extent than in Uganda. ${ }^{2}$ Not all these changes, of course, can be attributed directly to growth; but it would be hoped that growth would provide an environment in which all non-income indicators could improve.

All this evidence, though, concerns the poorest, who are not necessarily the chronically poor; nor does it provide much information about the role of different factors in enabling exits and entries into poverty. This requires panel data to which the next two sections of this paper now turn.

\footnotetext{
${ }^{2}$ Why it has in Ghana to a significantly greater degree than in Uganda is an interesting question to be researched.
} 


\section{The chronically poor, poverty transitions and markets}

The chronically poor share many characteristics across the five countries in this project where they are explicitly identified: Ethiopia, India, Nicaragua, Uganda and Vietnam. They generally live in larger households with a higher proportion of children; they are disproportionately located in rural areas, and within rural areas are more likely to be working in agriculture; they have lower average levels of education. The chronically poor are frequently further away from key infrastructure. In India and Vietnam chronic poverty rates are, unsurprisingly, significantly higher among recognised disadvantaged groups: Scheduled Castes and Scheduled Tribes in India, and groups other than the Kinh-Hoa in Vietnam. Chronic poverty is also disproportionately concentrated in specific regions (the Northern and North West Departments in Nicaragua; Northern Uganda; the central and North-Eastern Hindi and Oriya speaking belt of India, and the Northern Uplands in Vietnam). These regions are generally characterised by poor growth performance; in other words, growth often has strong spatial patterns. This means that even when aggregate growth performance is good, some regions may be experiencing little growth if any. Frequently these regions are also where chronic poverty is disproportionately concentrated, and the same factors will often underlie the widespread chronic poverty and the absence of regional economic growth (as in Northern Uganda, where conflict and social instability is one key contributory factor).

All of this suggests that a regional development focus to policy makes considerable sense. There is a well-worn debate about how much attention to give to underdeveloped regions. Unfortunately this debate has been marred by an absence of nuance: in the policy discourse regions are classified dichotomously as low/high potential; favoured/less favoured; developed/underdeveloped; plains/mountains; coastal/inland. Among the less advantaged regions there are often regions or areas which - while not the most well-endowed, still have potential. It is these regions which should perhaps be the particular focus of policy. ${ }^{3}$

Those escaping from poverty are often better endowed in terms of many key characteristics, including assets, proximity to infrastructure etc., and are less likely to be located in lagging regions or among marginalised groups. In Vietnam most of the urban population escaped poverty between 1993 and 2004, although it is important to remember that by definition the panel data sets will not pick up many recently arrived urban migrants, a group among which deprivation tends to be high. Evidence from the Uganda and Vietnam panel data sets might suggest that there is greater

3 A CPRC workshop in March 2007 is addressed some of these issues: see http://www.odi.org.uk/pppg/poverty and inequality/Events/2007 Spatial Poverty Traps/inde $\underline{x . h t m l}$. This is also a major aspect of CPRC's further work on economic growth. 
dynamism in urban labour markets, but there is not enough evidence to suggest that this can be generalised. By contrast, descents into poverty - which are significant in number, even in fast-growing economies such as Vietnam - tend to be associated either with life-cycle factors, or with adverse shocks (e.g. droughts). The case of Ethiopia, in particular, shows strong evidence for the highly persistent nature of such shocks, with some evidence even that livelihoods in 2004 had not fully recovered from the severe 1984/85 famine.

In relation to changes in consumption at the household level, in Uganda those households that escaped poverty in the 1990s unsurprisingly show the largest proportionate increases, but the study does not provide enough information to judge how far the poor move above the poverty line - which is potentially correlated with whether the escape from poverty is more likely to be permanent. The chronically poor in Uganda show much smaller relative increases, but at least they do show real increases. Earlier analysis of the panel data set in Uganda (McKay, 2005) in fact showed considerable mobility among these households, with high average increases in consumption among the poorest deciles (though to some extent this conclusion will be affected by measurement error). Nonetheless, there is evidence of increases in consumption levels for the chronically poor over the 1990s. At the same time, an important number of households experienced large reductions in consumption levels and fell into poverty as a result.

In Vietnam, where, exceptionally, there are two separate panel data sets within the national household surveys, 1993-98 and 2002-04 (without overlapping households between the two panels), there is evidence for a substantial reduction in chronic poverty from $28.7 \%$ in the first panel to $16.4 \%$ in the second. This reduction though is observed much more in some locations (e.g. Red River Delta) than others (e.g. Central Highlands), and was much greater for the Kinh-Hoa majority than for most ethnic minority groups. In policy terms this reinforces the importance of regional development policy, and/or also suggests that policies towards marginal (ethnic or otherwise defined) groups will also be important.

In terms of explanations for participation in growth, this project has sought to look specifically at the role of markets and the extent and terms of participation by the chronically poor, focusing specifically on the commodity, labour, financial and housing markets. In practice this is not always straightforward to identify from household surveys - for example, there is reason to think that participation in casual labour markets may be under-reported, perhaps especially agricultural markets. The difficulty of collecting reliable information on participation in credit markets, especially the most informal forms, is also widely known, and this may also apply to other financial markets. These issues are probably less serious for participation in commodity markets (as buyer or seller) and, in the relatively few cases where they exist, housing markets.

Participation in markets is shown in the country studies to be an important factor associated with escapes from poverty, and preventing descents into poverty. This is 
perhaps especially striking in the case of Ethiopia, where participation in commodity markets in nearby small towns as buyer and seller are identified to be very important in raising consumption levels: through selling agricultural output, purchasing inputs and selling non-agricultural handicrafts for which there is unlikely to be a market in the village. The ease of accessing markets is strongly associated with transport infrastructure, in particular roads. The importance of markets in preventing descents into poverty suggests that market access has also played an important role in reducing insecurity. Infrastructure, in general, is a factor which comes out very strongly in almost all countries in enabling escapes from poverty. Those lacking good infrastructure tend to be cut out of participation in more profitable market opportunities, or alternatively need to sell or buy - perhaps to traders - on less advantageous terms. In other words, infrastructure improves the terms on which the chronically poor access markets, including reducing transaction costs.

Participation in non-agricultural labour markets is also identified as a key correlate of escaping poverty or of being non-poor to begin with. But accessing such employment opportunities typically requires sufficiently high levels of human capital (education, health) to begin with, which, of course, excludes many of the chronically poor. Investment in human capital is clearly important, but in the short to medium term the better opportunities for the chronically poor are likely to continue to be centred around small-scale agriculture. The chronically poor are more likely to participate in agricultural labour markets, but such labour markets are often very limited, reflecting deficiencies on both the labour demand and labour supply sides, a point which is particularly striking in Uganda and Nicaragua. The Uganda study reports a strong preference for working on one's own land rather than on someone else's, even when the return on one's own land is low. The labour demand deficiency in many countries reflects a lack of farmers with sufficient land and capital to be able to afford to hire workers. This latter issue seems to be the case even in Nicaragua where land ownership is highly unequal, and this is thought to be related to the underdevelopment of financial markets. This is a tentative conclusion, needing confirmation; but if confirmed for Nicaragua and perhaps other countries it has substantial implications for finance programmes - e.g. challenging the almost exclusive focus of donors on micro-finance. It suggests the need for a much stronger focus on finance for SMEs, trade and larger-scale farms, and that this may have benefits for the chronically poor. 


\section{Box 1: The Limitations of Rural Financial Services in Vietnam and Ethiopia}

Throughout the 1990s there were considerable developments to the financial services provided to agriculture and the rural economy in Vietnam, with rural credit growing at an annual rate of 24-27\% form 1993 onwards (Ministry of Trade, 1999). The Vietnam Bank for Agriculture and Rural Development (VBARD) was created in 1988 to provide funding to rural enterprises, and expanded its operations significantly both in terms of number of beneficiary farmers and the volume of capital provided - the share of credit going to agricultural households increased from 14\% to $79 \%$ between 1991 and 1995, and the share of loans to agricultural state enterprises declined correspondingly (Jamal and Jansen, 1998). It is currently the largest supplier of formal financial services to rural households, accounting for 84\% of outstanding loans provided by formal lenders by 1998 ( $\mathrm{Ho}$, 2004), and the network of VBARD branches reaches to village level using the model of village banking and/or mobile banking. Yet, the services provided still present some important limitations: first, loans of 1 million VBD, a sum considered large for the poor, represent only about $16 \%$ of total loans provided by the VBARD; second, there is a collateral requirement to access credit. (such residential property, movable assets, goods and land use rights' certificates) but only about $30 \%$ of rural households have land use rights' certificates and the majority of the rural poor are unable to respond to the collateral requirement; third, SOES: there is a preference for providing credit to SOEs because credit amounts are larger, transaction costs relatively small and risk is low. Due to these constraints, the informal finance system (especially from relatives) still constitutes hence an important alternative to the rural poor, representing about 51\% of loans to rural households in 1998 (Putzeys, 2002).

In Ethiopia, the liberalisation of financial markets was an important component of structural adjustment. The reform package, introduced at the end of 1992, included the reorganisation (not privatisation) of the existing state-owned financial institutions into the new market-oriented policy framework, reformulation of the central bank's supervisory role - the National Bank of Ethiopia (NBE) - and the creation of a regulatory framework for the emerging privately owned financial institutions (see Assefa Admassie, 2004). As a result of these measures the share of the private sector in total domestic credit has rose from 12\% in 1991 to $54.8 \%$ in 1999 (Addison and Alemayehu Geda, 2001). However, agricultural finance remains heavily controlled by the state raising questions about the scope of the liberalisation reforms. Regional governments act as intermediaries between the banks and farmers, using their federally allocated budget as collateral to borrow funds from financial institutions which are then lent to farmers.

The share of agriculture in total credit is low given the size of the relative agricultural economy, averaging only around 16\% between 1994/95 and 2001/02 (Assefa Admassie, 2004). Moreover, agricultural financial services have very little coverage - the bulk of financial services provided to small and micro-enterprises in rural and urban areas originates mostly from the informal sector such as lqqub, money lenders and friends (ibid.). Despite the emergence of micro-finance initiatives through the late 1990s, and a supportive regulatory framework (that lifted interest rate ceilings on loans, and increased repayment periods) micro-finance services in Ethiopia still have very limited coverage, especially amongst the chronically poor: measures to achieve this might include an incentive system for the provision of very small loans demanded by the very poor (which involve higher transaction costs); and a well-functioning and efficient legal system to enforce contracts and clear property rights.

Summarised from Cabral (2006a, 2006b) 
Financial markets do appear to be the most underdeveloped market of all, and one which is potentially very important - partly indirectly - for the chronically poor. The main issue here may not be access to credit; on the contrary this may lead to cycles of impoverishment through debt as argued in the Nicaragua study. Other forms of financial services - insurance, secure savings mechanisms - may be much more important. Here, the nascent experiences with micro-insurance and the more mature experience with savings groups (for example in India) need to be evaluated. But in addition, as argued above, better-developed financial markets in general may lead to enhanced development of markets that do matter for the chronically poor.

\section{Box 2: Micro-insurance for the chronic poor?}

The country papers that informed this study only touched upon micro-insurance initiatives in terms of their absence - Dercon et al (2006), for instance, highlight how credit programmes offering fertiliser in Ethiopia did not include a drought insurance component, but that defaulters in drought years - such as 2002 - were dealt with harshly. Bundled micro-insurance within such a credit programme could transfer risk, and reduce default. There is an emergent literature on (non-health and -life) micro-insurance, with some seeing it as a panacea (see Hess and Syroka, 2005) and others taking a more measured approach (see Mechler et al, 2006). It is important to recognise that insurance reduces the risk of short-term loss, but does not address the inequalities that create the risk in the first place. Further research is essential. There are, of course, problems with ex ante micro-insurance, including: verification, contract enforcement by the poor, and the need for regulation of micro-insurance providers so that reinsurance can keep premiums low.

The practical experience of insuring low-income households against natural hazards shows that, despite the limitations noted above, such ex ante insurance appears preferable to ex post measures (such as safety nets or social protection) as it promotes increased self-reliance and lessens dependence on ad hoc measures (Mechler et al, 2006). Traditional crop insurance relied on paying out on actual losses, necessitating very high transaction costs. The recent development of indexbased insurance using not losses, but a surrogate trigger - often a rainfall shortage as measured at a regional weather station - offers a highly feasible alternative. Promoted by the World Bank, and often distributed through micro-finance institutions, such schemes are highly transparent, avoid verification problems, but, due to the covariance of climatic shocks, increase the need for reinsurance. Such formal schemes can include a number of actors, singly or jointly: central or local government, NGOs, CSOs, donors, and, of course, the private sector.

Donors can support measures to promote micro-insurance, including making such products accessible to the poor, and focusing on prevention (especially in the context of climate change) can maximise the pay-offs from limited disaster aid budgets. Premiums for micro-insurance are not cheap, not least due to the inflated costs of reinsurance within a Southern context, making such schemes outside the scope of the severely poor and the chronically poor. However, making insurance available can be achieved, even in high risk areas, through: reducing transaction costs through using NGOs and MFIs to provide low-cost administration channels and 'club' models to increase the reliability of payments; getting government or donors to provide capital for reinsurance (for example the Global Index Insurance Facility), and to subsidise premiums for the poor; or through tying insurance with micro-credit so that very premiums just cover loan default, and not livelihood losses. The perceived integrity of all actors in the insurance field is key - trust is vital for micro-insurance to succeed - stakeholder participation in the design of schemes can foster such trust, as does payments (see Mechler et al, 2006). 
Land markets for both rental and sale are highly underdeveloped in most countries. Tenure insecurity is identified as an important issue in Ethiopia and Nicaragua, in different ways. Tenure insecurity in Ethiopia is identified as a major factor underlying low levels of investment there (though in other work Devereux et al (2005) argue that there is too much tenure security). In Nicaragua, the absence of a well-developed rental market is identified as a major problem, possibly again linked to underdevelopment of financial markets. The rental market is likely to be the form of land market which is most relevant to the chronically poor (see Section 4).

\section{Urban issues}

There is much more evidence available on many of these issues in rural areas compared to urban areas. The urban chronically poor are often be engaged in casual, frequently insecure, self-employment activities rather than working as employees -and obtaining a wage job is often an important means of escaping chronic poverty. The public sector is a potential source of such jobs, but in many countries it has been scaled back. But even without this retrenchment, the public sector has generally been much less likely to employ the chronically poor given general excess demand for such jobs. The extent of urban private-sector employment opportunities varies from case to case. Vietnam is an emphatic success story in terms of employment creation, and there has been some progress with employment creation in some Indian states. However, in many African countries employment creation in the private sector has been very limited, partly due to an unwillingness to invest. When investment has occurred it is often difficult to mobilise and maintain in the face of stiff competition in global markets, and often also a difficult policy environment. This is the case in Uganda, where it is not fundamentally an issue of a lack of investible resources, but a preference - often also in the banking sector - for investing in other forms such as construction or domestic or foreign financial assets. In the absence of wage employment opportunities, the urban chronically poor may have no option but to rely on insecure self-employment activities, among which trading may be particularly important.

The housing market is a fundamental concern in urban areas. Informal settlements surrounding cities (where the chronically poor are likely to live) are insecure, marginalised from the main centres of economic activity and much less likely to be provided with adequate infrastructure services including those important for economic activities (e.g. electricity). A lack of convenient access to water and fuel may impose additional time costs; and the transaction costs of accessing education and health facilities are likely to be much greater than those living in more organised settlements (Grant, 2006).

The issues in small towns may be rather different from those in larger and capital cities, in terms of livelihood profiles, services, etc., but unfortunately there is very little quantitative analysis which distinguishes between large and small towns. This partly 
reflects inadequate sample size problems. Small towns, though, have clearly been seen to be very important for rural hinterlands in the case of rural Ethiopia above. This remains a significant gap in poverty research. 


\section{Key issues in facilitating escapes from chronic poverty}

The evidence base available from the country studies is limited to a significant degree by the information available from the household surveys; there are a limited number of waves in panel surveys, and the surveys often do not report a lot of information on the role of different markets. The country studies focus on only five cases (reflecting the still limited availability of panel data), and only some of these include urban poverty. But despite these caveats, combining these studies with the authors' knowledge of the countries, does enable important insights to be drawn about the factors which permit the poor, and potentially in the future the currently chronically poor, to escape from poverty by participating in growth. Based on the studies conducted in this project, the following appear to be key elements.

\subsection{The core role of urban growth}

It is clear that, in a growth environment, urban areas play a key role in the processes that generate growth and associated poverty reduction (Grant, 2006). This is especially evident in the cases of Vietnam and India studied here. In urban areas there are significant benefits from agglomeration economies, hence encouraging greater investment (given also the right investment climate); the urban financial sector can be much more highly developed; and public services can be provided more cost effectively in urban areas - and potentially with greater accountability. Urban growth potentially offers substantial poverty reduction benefits if the poor in general, and the chronically poor in particular, are able to participate. As argued above, growth in urban areas - including smaller towns - offers important benefits to the rural areas to which they are connected. The ability to transact in urban markets offers significant benefits (though also possible risks, for example through greater availability of imports competing with local production). Migration to urban areas and associated remittances also offer important benefits to rural areas. However, migrants from less developed areas often achieve lower returns to migration partly because their levels of human capital are lower - a potentially important area for intervention to support such migrants. Urban development also offers important benefits through its impact on rural wage labour markets - increasing the competition for labour, and so pulling up wage levels.

But there are downsides to urban growth. Across different countries there is evidence of increasing inequality with urban growth (as in the case of Vietnam here); and evidence in some countries of increasing urban poverty despite growth. The latter is partly a consequence of increased urbanisation due to migration. But both phenomena also partly reflect the difficulty that many migrants have in integrating into urban labour markets, compounded in many cases by insecure housing. The extent of this is inevitably underestimated in panel household surveys, which will cover less the newly arrived migrants. Within urban labour markets there is evidence 
in many cases of an increased premium for skills, usually to the disadvantage of the chronically poor who frequently lack skills. Urban labour markets have often also become increasingly informal; and the insecurity that this generates is likely to have particularly severe impact on the chronically poor, who will often have limited access to mechanisms to cope with this insecurity. Nonetheless, the opposite extreme of highly rigid urban labour markets, such as those in Ethiopia, is not good for either growth or the chronically poor (who generally do not participate in these markets; Kedir and McKay, 2005). Moreover, migrants from rural to urban areas are often not from the poorest rural households (perhaps because of a lack of human capital); consequently the rural chronically poor often miss out on remittance flows.

Poor macro-economic management has been shown to have a particularly severe impact on poverty in urban areas, where alternative options to current employment may be limited (especially in a recession situation). The chronically poor or the poorest may be directly affected less than richer households by this (they may be less likely to hold the wage jobs that may be lost) but there can still be important indirect effects for the chronically poor (e.g. demand for informal sector activities, remittances, withdrawal of children from school). There are also likely to be important adverse effects on wages in the casual labour market, reflecting increased supply of and/or reduced demand for labour.

Despite the fact that urbanisation and urban growth have frequently not benefited the chronically poor proportionately, it remains a very important component of a strategy to tackle chronic poverty. Some chronically poor households have been able to escape poverty in growth environments (the case of Vietnam, while exceptional, is nonetheless illustrative). Urban growth also creates more resources which city authorities could choose to use to address key problems for the chronically poor. But most important of all perhaps, urban growth provides important opportunities for neighbouring rural areas.

Urban development has typically been viewed by policy makers in a narrow way the issues and impacts conceptually contained within the city boundaries, rather than looking to maximise the positive effects of urban development for the economy and society as a whole. This analysis suggests the need for aggressive national urban policy making which might: plan infrastructure in order to link poor regions with economic potential more effectively to urbanising regions; systematically encourage the urbanisation of poor regions where growth is limited; enact policies so that urban labour markets do not discriminate against disadvantaged categories of people.

The geographical structure of local government may not help much in this regard. Urban municipalities are frequently governed separately from their hinterlands (except in the Iberian tradition), and local planning and development decisions are frequently taken within a framework of largely or purely urban interests. Moving away from this through national urbanisation strategies, regional development planning frameworks, and even the representation of hinterland interests in urban municipal governance are possible ways forward. 


\subsection{Provision of relevant infrastructure}

This issue comes out very strongly in some of the country studies, with one of the most important factors being that better infrastructure enables households - including the poor - to participate more effectively in markets (as sellers and buyers), a factor which Section 3 above suggests is generally beneficial. One important aspect of this is directly related to the immediately preceding discussion about the links between rural and urban areas. The importance of village infrastructure comes out strongly in India, and roads are identified in Ethiopia as one of the single most important factors. In Ethiopia, links to small town markets provide opportunities for the development of non-agricultural production activities, offering important diversification benefits. Other important dimensions include urban infrastructure relevant to the chronically poor, such as electricity, drinking water and sanitation; the absence of which may have adverse impacts on economic activity or health.

Infrastructure has been less emphasised in Poverty Reduction Strategies in Africa than elsewhere (Shepherd and Fritz, 2005). However, resource flows into infrastructure are now picking up even in Africa, especially with the entry of the Chinese and other new actors into aid and private investment. The key issue emerging from the country level research for this study is the importance of tailoring infrastructure (and service) investments to local specificities. This implies a degree of devolved decision-making, or centralised decisions which are very mindful of local variation and future economic opportunities. A national urban policy would help in this regard, as would decentralised (not necessarily devolved) public sector infrastructure agencies, able to respond to local level needs

\section{Box 3: Investment in Infrastructure in Vietnam}

In Vietnam, irrigation has been considered one of the priority policy areas to enhance agricultural productivity and reduce poverty, with public investment in irrigation accounting for about $60-70 \%$ of the agriculture sector's budget (Que and Que, 2000). Between 1993 and 2000, investment in irrigation systems increased substantially both at national (12.4\% a year) and provincial (19.4\% a year) level (Fan et $a$ l, 2003). The regional distribution of irrigation expenditure shows that Red River Delta, Mekong River Delta, North Central coast, and South East region accounted for about 60-80\% of total investment (Que and Que, 2000). Comparing these investment patterns with poverty dynamics from 2002 - 2004 shows mixed trends: the Red River Delta showed the greatest reduction in its share of national chronic poverty, and the Mekong River Delta had the greatest share of those exiting poverty. On the other hand, the North Central coast and South East performed relatively poorly (Thang et al, 2007). Moreover, Fan et al's (2003) econometric analysis indicates that irrigation investment had the smallest impact on poverty reduction and agricultural growth. Similarly, Vietnam invested substantially in the expansion and rehabilitation of the road network - the national average road density increased from 0.46 to $0.52 \mathrm{~km}$ of road per square kilometer between 1994 and 1998, and about $87.9 \%$ of all communes are connected by roads accessible for vehicles (Que and Que, 2000). But again, the considerable regional disparities in road density persist. The road network still under-developed in the poorer regions - especially the Northern Uplands - and there is evidence that about $85.9 \%$ of the communes without accessible roads are poor (Fan et al, 2003).

Sı ımmariced frnm C.ahral (วกกЋa) 


\subsection{Education and skill formation}

In rural areas, households who access non-agricultural activities are significantly less likely to be poor; education levels are particularly important in this regard. But education levels also have significant positive impacts on productivity in agriculture, the activity in which many the majority of the chronically poor are employed - and will be for the foreseeable future. The education levels required to assist people out of poverty vary from place to place: thus in the Vietnam hills lower levels of education were required than on the plains.

Finally, education is also very important in relation to migration to urban areas, which for many can be an escape route from poverty. More educated people are more likely to migrate in the first place; and more educated migrants have a better chance of obtaining reasonable employment. One of the reasons that migrants from less developed regions gain lower returns from migration is the low levels of education they have obtained. Education improvements would represent a significant aspect of regional development policies. Most migration remains rural-rural, however, and here the impacts of education may be different: Mosley (2004) found in Bolivia and Uganda that educated rural casual labourers were more likely to be able to bargain for better wages.

As already argued, in urban areas there is typically a substantial premium to skills, and in some cases this premium may be rising. Lack of education or skills will often trap the chronically poor in low-paid activities which do not allow them to escape from poverty. In urban areas, development of relevant skills (as well as networks, etc.) is a key component of seeking to escape from poverty; but, at the same time, a lack of urban employment opportunities continues to be a major constraint, and in turn reduces the incentives in those cities to invest in education or training. Various different factors account for the lack of employment creation in many countries; again an unwillingness to invest, where this can reflect various factors including perceived risks, sometimes the difficulty of appropriating the benefits of the investment, or underdevelopment of the financial sector.

Education systems have frequently failed the chronically poor. In rural areas, schools - especially post primary - tend to be much less accessible to those in remote areas where the chronically poor are often concentrated, and the quality of the education tends to be much poorer. The opportunity - and monetary - cost of sending children to school may be very high, and the benefit may not be apparent to chronically poor parents, who need to address short-term needs as opposed to longterm prospects. There are also children who are neither in school, nor work 'children at home, an issue on which little is known in relation to chronic poverty. In urban areas there are often strong neighbourhood effects with poor quality of schools (and an absence of role models) in the localities where the chronically poor live. 


\subsection{Information}

The chronically poor typically suffer from poor quality social capital, with the consequence that access to important information may be a major constraint: for example, information on job opportunities, on markets for outputs or on new farming techniques. This lack of information may be a major factor accounting for the persistence of poverty. Information about commodity markets may be a key priority for agricultural producers, and information about labour market opportunities for many of the chronically poor. Agricultural extension services have been a traditional means of informing farmers about improved production methods: use of inputs, new varieties of seeds etc. But the country studies here provide mixed evidence at best about the effectiveness of extension services in improving living conditions. In rural Vietnam extension centres seem to have played an important role in helping some ethnic minorities escape from poverty. But in rural Ethiopia those households that had been visited by extension agents were not more likely to use fertiliser - regarded in that study as the key factor for increasing production - than those that had not received visits.

A key question for future research work is the extent to which modern information demands are satisfied through extension services, or through a wider spectrum of private and public agencies which have information provision as a spin-off, sideline or major component. Recent assessments have focussed almost exclusively on ICT; it is time to look more widely at information sources and their impacts. For example, FM radio, contract farming companies, traders and enterprise/farm input suppliers may be much more powerful and accessible sources of economically useful information. Providing wider access to (cell) phone services may also be an important dimension of this; and improved road and other infrastructure, as well as higher education levels, are also likely to help in the flow of information.

\subsection{Reducing insecurity}

There is now a very strong body of evidence that insecurity has an adverse effect on growth, especially pro-poor growth, as it is the poor that typically face the highest levels of insecurity. This is especially apparent in the case of rural Ethiopia, where production insecurity is identified as a major factor having an adverse impact on production levels, and discouraging the adoption of improved production methods. And as argued above, adverse shocks frequently have a high degree of persistence. High variability of production levels, prices etc., means that it is very difficult to attain sustained smallholder agricultural growth.

Governments can, however, create a less-risky enabling environment. They can: leave markets to function without excessive interference; provide infrastructure to facilitate better functioning markets; emphasise and invest in financial services for SMEs including agriculture - at least to support financial institutional development; provide or enable the provision of a variety of social protection mechanisms which insure poor people against the most important risks they face; invest heavily in 
education for the poor, especially post-primary where economic impacts are likely to be greater; provide a strong agricultural research and extension environment; and even establish commodity price floors and ceilings for strategic commodities.

In general, the chronically poor have less convenient access to mechanisms to help them cope with insecurity. Food aid distribution mechanisms in Ethiopia are seen to have some impact in reducing insecurity even if the targeting is not always very accurate; even when it is inaccurate there are still often indirect effects (Ethiopia has, though, been moving towards strategic safety nets and broader social protection measures). Greater development of financial markets which can serve the chronically poor, in particular opportunities for savings and insurance rather than small-scale credit (which as noted above may result in a deeper poverty trap) offer one important means of reducing insecurity.

\subsection{Wider factors}

In addition to the five key factors outlined above, three further issues emerged from some of the country studies: access to land; attaining inclusive transformative growth; and excluded groups and regions.

First, lack of access to land is an important issue behind chronic poverty in Nicaragua due to the highly undeveloped nature of the land rental market, a fact attributed to the high degree of inequality, the underdeveloped nature of the financial market and to simple risk aversion. In Ethiopia, lack of security of access to land (which can be reallocated by the local Peasant Association) is considered to be a major factor discouraging investment in land and adoption of improved production methods.

Second, the country studies highlight the challenge of attaining inclusive transformative growth. While consumption levels improved overall during the ten years of the Ethiopian rural panel survey, growth rates were slow, and the pattern of incomes changed very little over the period; the relative share of agriculture - and each other income component - at the end was very similar to their values at the beginning. Consumption levels increased on average and poverty levels fell; but this was very much not transformative growth in the East Asian sense, or as seen here in the case of Vietnam. Such transformative growth in Vietnam has been associated with a substantial - if selective - reduction in chronic poverty over a relatively short period of time. The major challenge is how and under what conditions such transformative growth can be realised. And where it cannot, what other paths are available?

Changing structures of income and reduced reliance on agriculture will be necessary to sustain good growth performance; but this by itself may not be sufficient to reduce the degree of risk and insecurity with which poor households are faced. Risk and insecurity in agriculture can be reduced through appropriate policy interventions, and the non-agricultural activities into which farmers may move (e.g. informal trading 
activities) are not necessarily less risky. As we have seen, agriculture itself is capable of providing significant security if well managed.

Broad-based growth performance is likely to require growth across several sectors and sub-sectors simultaneously, including agriculture. It is also much more likely where there is reasonably equal access to basic assets (land, water, livestock, housing, education) at the starting point of a growth process - implying that measures to enhance equality at the beginning of a growth process may be especially critical. This may also help with the more challenging task of sustaining the growth process.

Third, and as noted above, a substantial proportion of chronic poverty tends to be concentrated in lagging regions or among disadvantaged groups; and growth and relatedly poverty reduction tend to be slower among these groups. This was the case even in the situation of transformative growth in Vietnam. The issues that need to be addressed in these lagging regions/groups include many of those listed above, but with particular focus on these regions or groups because there initial levels of assets, opportunities etc are likely to be lowest and have lowest returns. There may though also be important political dimensions to this, or other factors such as discrimination at work. This needs to be considered on a case by case basis. The good news is that increases in the low levels of assets may have quite powerful poverty-reducing effects (the Vietnam hills education story); the more difficult news is that infrastructure investments need to be tuned to local/regional priorities, which is more difficult to achieve. 


\section{Supporting Growth in Difficult Policy Environments}

This section focuses on chronic poverty and markets in three 'fragile' state environments (Zimbabwe, Sudan, Malawi). State 'fragility' reconfigures and stymies the 'conventional' relationship between economic growth and the chronically poor discussed in Sections 2 - 4. As already seen, insecurity and shocks have adverse affects on growth and the extent to which the chronically poor are able to participate. State 'fragility' or failure increases the frequency and severity of such shocks, some of which may even be perpetrated by the state itself.

Moreover, examining the relationship growth and the chronically poor in these environments is difficult and complex - not only are 'fragile' states highly heterogeneous (the term 'fragile' states is an unhelpful composite of varying degrees of political will and institutional capacity (DfID, 2005)), but growth trends in 'fragile' states vary widely, as exemplified in our three country cases: strong oil- and construction-led growth in Sudan; highly variable agriculture-led growth in Malawi; and rapid economic contraction in Zimbabwe. As a result, it is not possible to draw strong generic lessons about shared growth from these cases. Instead, we focus on how there is a substantial overlap between reducing chronic poverty in these contexts, and addressing some of the drivers and maintainers of 'fragility'. Fragility is likely to have adverse effects on growth. But it may especially limit the potential for poverty reduction if any growth that occurs can be captured by a small powerful group. Overcoming this is likely to be happen through fostering the 'social contract' between citizens and the state.

The literature on 'fragile' states is almost entirely macro - focused at the international comparative and national level, trying to tease out the correlates, causes and impacts of conflict and state failure. The econometric literature shows that income growth is key to avoiding 'fragility' - no country with a per capita income of more than US\$6000 has experienced civil war (Vallings and Moreno-Torres, 2005), and economic stagnation has been found to increase the probability of internal war in several studies (US Government, 2000; Collier, 2006 and 2004). Therefore, growth provides not only intrinsic benefits, but also instrumental benefits. Whilst developing countries as a whole, and low-income countries in particular, are at risk of 'fragility', economic growth can clearly reduce this likelihood. However, such econometric correlations tell us very little about the specific mechanisms and processes through which growth reduces 'fragility'. One such mechanism is the extent of the 'social contract' between state and citizen, and the concomitant character and level of inequality.

In short, the 'social contract' can be understood as the agreed and adhered to institutions through which conflict, disagreement and excessive inequality are 
resolved. ${ }^{4}$ When the 'social contract' is well formed, it creates norms and expectations around how individuals interact with each other (politically, morally, and economically). Importantly, these norms and expectations increase mutual benefits and reduce costs. When these 'rules of the game' are largely adhered to, the social contract fosters high levels of trust, reducing the chances of being exploited by others, and increasing investments in long-run activities, stimulating growth. Conversely, a poor 'social contract' and a lack of institutions through which to settle disagreements, increases the chances of exploitation, and increases individual's uncertainty about the future, making investments more short term (increasing individual's discount rates) (Addison and Murshed, 2004).

Importantly, the nature and negotiation of the 'social contract' alters with patterns of growth - not only through participation in, and sharing the benefits from, growth, but through the creation of new political and social forces. Moreover, the most important element in the creation of a 'social contract' revolves around inequality: latent differences can become politically charged and easily contribute to state 'fragility' especially in terms of access to assets and employment, the certainty of social protection and the distribution windfalls (ibid.).

We now outline the patterns of growth in our country cases, and suggest that equal access to food and equitable labour markets are two instruments through which donors might be able to reduce chronic poverty, and foster the social contract, within 'fragile' environments. The country cases showed how skewed growth patterns (in terms of commodities, or socio-spatially) can contribute to fragility (oil in Sudan, tobacco in Malawi) or reinforce it (shift to mining and extractive industries in Zimbabwe). Donors need to be mindful of how aid resources can reduce (chronic) poverty within such lopsided economies, bearing in mind the political forces around primary industries.

All three cases illustrate how hunger is the clearest symptom of the failure of the social contract between citizens and the state. We have seen that the chronically poor have the least convenient mechanisms to cope with risk. As traditional forms of protection against risk break down, a modernising state has the opportunity to create or facilitate new mechanisms which provide some stability and security, allowing people to live a decent life, and invest in high-risk high-return activities. Famine prevention is perhaps the most widely recognised social protection function of the state, and is one that is vital for any chances of reducing chronic poverty. However, it is one that the state has failed to provide in all three cases (for many different reasons), fracturing any chances of a 'social contract' and exacerbating 'fragility'.

The further policy area with a substantial overlap between reducing chronic poverty and fostering the social contract is the operation and performance of labour markets. In non-fragile environments we have seen how the rural chronically poor are most

\footnotetext{
${ }^{4}$ This section relies upon Addison and Murshed (2004)
} 
likely to participate in agricultural (as opposed to non-agricultural) labour markets, but that these are frequently very thin, reflecting deficiencies on both supply and demand sides. In the Sudanese case, investments in facilitating integrated labour markets can be seen as being a priority, as well as combating discrimination in local labour markets, with such policies dovetailing with the previous findings on regional planning and infrastructure. In such large countries, focusing development attention in remote, underdeveloped regions - even if this takes the form of facilitating improved conditions for (e)migration and social assistance to enhance the demand for education and health - a critical way of preventing the emergence of 'ungoverned spaces' of the future.

In Zimbabwe, labour markets have shrunk as demand declined due to closed or redistributed commercial farms, work arrangements have become less secure, and there is increased payment in kind, especially for agricultural labour. Moreover, state repression of the expanded urban informal sector through Operation Murambatsvina (as self-employment constituted the most significant form of urban labour for the chronically poor), the rapid contraction of the private sector, and persecution of those conducting informal gold panning, have further limited labouring opportunities. Whilst donors have recently started to focus on labourers and labour markets, there was a pre-crisis reluctance to engage in issues to do with farm labour. Some authors even argue that the retrenchment of urban workers through the 1990s and their return to rural spheres gave an added impetus to the political forces, such as the so-called 'war veteran' movement, that Mugabe utilised in the destructive and botched Fast Track Land Reform process (Addison and Laakso, 2003). Clearly, the current operation of labour markets are vital for reducing chronic poverty in Zimbabwe, illustrating the need for external donors to avoid 'path dependence' and have an innovative and dynamic approach to addressing the problems of poor people in 'fragile' states. ${ }^{5}$ Moreover, attention to labour markets prior to economic collapse may have reduced some of the drivers of state 'fragility' itself.

In Malawi, rural labour markets are critical for the chronically poor, but have not been given the explicit attention they deserve. In contrast, donors have been keenly and disputatiously interested in food security, and have also pressed for the inclusion of a strong focus on social protection in Malawi's Poverty Reduction Strategy (both of which only indirectly relate to rural labour markets). More direct engagement (such as the possibilities of guaranteed employment schemes) with rural labour markets, and a greater understanding of local ganyu patterns and intra-rural migration, would complement food security and social protection measures, limit inequality, and foster the 'social contract'. Malawi remains reliant on inflows of foreign exchange from annual tobacco auctions (predominantly burley tobacco), which is now mainly grown by smallholders. However, there is a near complete dearth of understanding of how the recent shift from estate to smallholder production has impacted on local and

\footnotetext{
${ }^{5}$ For example, DfID has been supporting the Farm Community Trust of Zimbabwe (FCTZ) - created by the Commercial Farmers' Union and Save the Children - for two years.
} 
district labour markets. Moreover, the lack of diversification in the economy reflects broadly similar investment patterns to those noted earlier in Uganda. Booth et al (2006) highlight how the UDF government under President Muluzi has not prioritised agricultural or industrial diversification strategies to produce tradeable goods, but that investment has been in commercial trading, transport, and property. In the context of stop-go aid flows, retail and distribution has lower set-up costs and faster turnover, requires less borrowing, and has thus been less affected by the high interest rates caused by macroeconomic instability. Such investment patterns only reinforce Malawi's skewed growth pattern and exposure to terms of trade shocks, and do nothing to aid prospects of transformative growth.

This section has highlighted how state 'fragility' reshapes and alters the 'conventional' relationship between economic growth and the chronically poor, not least due to variable growth patterns, and through the vital issues of political will and institutional capacity. This section has highlighted how there is a substantial overlap between reducing chronic poverty in these contexts, and addressing some of the drivers and maintainers of 'fragility' through fostering the 'social contract' between citizens and the state. We now turn to the definite and more speculative conclusions from this synthesis. 


\section{Conclusion}

There are two types of conclusion to be drawn - more and less definitive. Among conclusions for which there is significant evidence are the following:

- Urbanization plays an important and undervalued role in inclusive economic growth. National urbanisation policies, linked to infrastructure policies, can enhance the extent to which chronically poor people benefit from growth, especially when urbanisation is spread into poor regions.

- Infrastructure development and maintenance is critical to the functioning of labour and other markets on which poor people depend. Appropriate infrastructure plans require an element of decentralised design.

- Agricultural growth is important in the transmission of growth benefits to the poor, even in a transformative growth scenario - indeed it is critical to that type of scenario; the sector also has buffer characteristics which need to be acknowledged and bolstered. Agricultural growth is especially important in slow growing economies. To the extent that it is possible, reducing agricultural growth year-on-year variability is critical - involving both marketand production-based measures.

- A much stronger understanding and analysis of labour markets is needed, especially but not only in difficult policy environments (or 'fragile' states), together with a willingness to explore support for public and private measures which can enhance the performance of labour markets.

- Enhanced human capital is vital to gain benefits from labour markets and migration; post-primary education is particularly significant, will increase the returns to migration out of very poor regions, and has wider benefits in terms of facilitating the turnaround of states from crisis.

- Having a regional development angle within policy is important: this may be minimalist, focused on little but human development and social protection; or more economically adventurous where warranted.

- Special measures are usually necessary to counter discrimination against marginalized groups.

Some of these act through increasing participation in the growth process, but others are also concerned with seeking to avoid processes by which the chronically poor are excluded from, or damaged by, economic growth. Both of these components are very important is seeking to build a growth process which can also effective in reducing chronic poverty significantly, and minimising the risk of households falling back into poverty. 
More speculatively, and requiring further investigations:

- Employment will be enhanced if financial reforms focus on providing working capital to SMEs or large firms; this could have a more significant impact than focusing on micro-finance.

- Information can play an important role in making markets work for the poor. This can be 'traditional' agricultural extension, but this is only one possible form, and it is likely that having access to diverse information sources will help poor people out of poverty.

- Secure access to land through rental markets will be more significant for the chronically poor (who often lack assets) than land tenure reforms focused on securing private ownership rights or land redistribution.

- Equality of access to key assets at the beginning of a growth process can be enhanced through redistributive measures. There are chronically deprived countries which are currently showing early signs of 'taking off' where this would apply. ${ }^{6}$

\footnotetext{
${ }^{6}$ Within his analysis of chronically-deprived countries (CDCs), Anderson (2007) shows that 11 CDCs have improved recent performance on growth and 14 on malnutrition: the 11 across-the-board CDCs with significantly improved performance in GDP per capita are (in descending order of their most recent growth rates in GDP per capita): Mozambique, Chad, Angola, The Gambia, Rwanda, Ethiopia, Tanzania, Niger, Cameroon, Senegal and Zambia (p.9-10); the 14 across-the-board CDCs with significantly improved performance in under-nourishment referred to are: (in descending order of their most recent rates of reduction in under-nourishment): Rwanda, Angola, Chad, Cambodia, Mozambique, Niger, Cameroon, Guinea, Senegal, Cote d'Ivoire, Central African Republic, Kenya, Malawi and Tanzania.
} 


\section{References}

Addison, T. and Alemayehu Geda (2001) 'Ethiopia's new financial sector and its regulation', Discussion paper No. 2001/55, World Institute for Development Economics Research (WIDER), United Nations University.

Addison, T. and Laakso, L. (2003) 'The Political Economy of Zimbabwe's Descent into Conflict' Journal Of International Development, Vol. 15, pp. 457-470.

Addison,T. and Murshed,S.B. (2004) 'The Social Contract and Violent Conflict' Unpublished manuscript on War, Intervention and Development prepared for The Open University

Anderson,E. (2005) 'Growth incidence analysis for non-income welfare indicators: evidence from Ghana and Uganda' Background paper for the Second Chronic Poverty Report

Anderson,E. (2007) 'Identifying chronically deprived countries: results from cluster analysis' CPRC Working Paper 70

Assefa Admassie (2004) 'A review of the performance of agricultural finance in Ethiopia: pre and post reform periods', paper presented at the international conference on 'The Agrarian Constraint and Poverty Reduction: Macroeconomic Lessons for Africa', Addis Ababa, 17-18 December 2004.

Besley,T. and Cord,L. (2007) 'Delivering on the Promise of Pro-Poor Growth: Insights and Lessons from Country Experiences' World Bank : Washington, D.C.

Bhide,S. and Mehta,A.K. (2006) "Agricultural Growth and the Chronically poor" Background paper for Second Chronic Poverty Report, Chronic Poverty Research Centre, University of Manchester, Manchester : UK.

Booth,D. and D. Cammack et al (2006) "Drivers of Change and Development in Malawi" ODI Working Paper 261, January 2006, Overseas Development Institute : London

Cabral,L. (2006a) 'Growth policies and chronic poverty in Vietnam since Doi Moi' Literature review for the Chronic Poverty Research Centre, August 2006

Cabral,L. (2006b) 'Growth policies and chronic poverty in Ethiopia during the 1990s' Literature review for the Chronic Poverty Research Centre, August 2006

Collier,P. (2006) 'Economic Causes of Civil Conflict and their Implications for Policy' Centre for the Study of African Economies, Department of Economics, Oxford University, April 2006. 
Collier,P. and Hoeffler,A. (2004) "Greed and Grievance in Civil War" Oxford Economic Paper 56, pp.563-595.

Dercon,S., J.Hoddinott and Woldehanna,T. (2006) "Growth and Poverty in Rural Ethiopia: Evidence from 15 Communities 1994-2004" Background paper for Second Chronic Poverty Report, Chronic Poverty Research Centre, University of Manchester, Manchester : UK.

Dercon,S. (ed.) (2004) 'Insurance Against Poverty' WIDER Studies in Development Economics : Helsinki, Finland

Devereux, S., A. Teshome and R. Sabates-Wheeler (2005) "Too much inequality or too little? Inequality and stagnation in Ethiopian agriculture", IDS Bulletin, Special Issue 'New Directions for African Agriculture, Vol. 36, No. 2. Brighton: IDS.

DfID (2005) 'Why We Need To Work More Effectively In Fragile States' Published by the Department for International Development, January 2005.

Fan, S., P. Huong and T. Long (2003) 'Government spending and poverty reduction in Vietnam', project report prepared for the World Bank funded project Pro-poor spending in Vietnam. Washington D.C. and Hanoi: International Food Policy Research Institute and Central Institute for Economic Management.

Grant, U. (2006) 'Urban economic growth and chronic poverty' Background paper for Second Chronic Poverty Report, Chronic Poverty Research Centre, University of Manchester, Manchester : UK.

Grant, U (2005) 'Pro-poor growth and the Poorest', Report to DFID Reaching the Very Poorest policy team: London

Grimm,M., Klasen,S. and McKay,A. (eds.) (2007) 'Determinants of Pro-Poor Growth: Analytical Issues and Findings from Country Cases' Palgrave Macmillan: New York, USA.

Hess, U. and Syroka, H. (2005b) 'Risk, Vulnerability and Development', Presentation at BASIX Quarterly Review and Insurance Meeting, Hyderabad, India, 21 October.

Kedir, Abbi M. and Andrew McKay (2005), "Chronic poverty in urban Ethiopia: panel data evidence", International Planning Studies, 10(1): 49-67.

Klasen, Stephan (2005). "Economic Growth and Poverty Reduction: Measurement and Policy Issues", OECD Working Paper No. 246, September 2005 http://www.oecd.org/dataoecd/42/14/35393795.pdf

McKay, Andrew (2005), "Relations beteween Growth and the Poorest", Background Paper for First Chronic Poverty Report, September, 2004. 
Mechler,R., Linnerooth-Bayer,J. and Peppiatt,D. (2006) 'Microinsurance for Natural Disaster Risks in Developing Countries: Benefits, Limitations and Viability' A

ProVention/IIASA study. Available from:

http://www.proventionconsortium.org/themes/default/pdfs/Forum06/Forum06 Microin surance Jan31.pdf

Ministry of Trade (1999) "Overview of the Agricultural Sector in Vietnam: Implications of the WTO Agreement on Agriculture", Hanoi.

http://www.undp.org.vn/projects/vie95024/agriculture.pdf.

Mosely, P. and A. Suleiman (2006) 'Agricultural policies against severe and chronic poverty - Cross-section analysis and country case studies for sub-Saharan Africa' Background paper for Second Chronic Poverty Report, Chronic Poverty Research Centre, University of Manchester, Manchester : UK

Mosley,P., A.Suleiman and B. Chiripanhura (2006) 'Escape routes from the rural poverty trap: evidence from three African countries' Background paper for Second Chronic Poverty Report, Chronic Poverty Research Centre, University of Manchester, Manchester : UK.

Mosley,P. (2004) 'Severe poverty and growth: a macro-micro analysis', Chronic Poverty Research Centre Working Paper 51, Chronic Poverty Research Centre, University of Manchester, Manchester, UK.

Que,N.T. and Que,N.N. (2000) 'Effects of Trade Liberalisation on Agriculture in Viet Nam: Commodity Aspects' Regional Co-ordination Centre for Research and Development of Coarse Grains, Pulses, Roots and Tuber Crops in the Humid Tropics of Asia and the Pacific. CGPRT Centre Working Paper 52

Ravallion,M. and Chen,S. (2003) "Measuring Pro-Poor Growth." Economics Letters 78: 93-99.

Putzeys,RE. (2002) 'Micro Finance in Vietnam: Three Case Studies' Unpublished MSc thesis, Faculty of the Political and Social Sciences, University of Ghent, Belgium

Rodrik, Dani (2004), "Growth Strategies".. Available at:

http://ksghome.harvard.edu/ drodrik/GrowthStrategies.pdf

Ssewanyana,S.N. and Bategeka,L. (2006) 'Chronic poverty and economic growth in Uganda: The role of markets' Background paper for Second Chronic Poverty Report, Chronic Poverty Research Centre, University of Manchester, Manchester : UK

Shepherd, A. and V. Fritz (2005) 'Key issues in sharpening the rural production focus of Poverty Reduction Strategy Processes: Literature Review for IFAD', Unpublished Issues Paper. ODI : London 
Suleiman,A. and Mosley,P. (2006) 'The poverty-reducing effect of increased food crop productivity in Ethiopia: A multi-market Analysis' Background paper for Second Chronic Poverty Report, Chronic Poverty Research Centre, University of Manchester, Manchester : UK.

Thang,N and L.D. Trung, V.H. Dat and N.T. Phuong (2006) 'Poverty, Poverty Reduction And Poverty Dynamics In Vietnam' Background paper for Second Chronic Poverty Report, Chronic Poverty Research Centre, University of Manchester, Manchester : UK.

US Government (2000) 'State Failure Task Force Report: Phase III Findings' September 2000. Available from:

http://globalpolicy.gmu.edu/pitf/SFTF\%20Phase\%20III\%20Report\%20Final.pdf

Vallings, Clare and Magüi Moreno-Torres (2005) 'Drivers of Fragility: What Makes States Fragile' PRDE Working Paper, April 2005.

Wiggins,S. (2006) 'Case study: Nicaragua' Background paper for Second Chronic Poverty Report, Chronic Poverty Research Centre, University of Manchester, Manchester : UK 